\title{
ORIGIN AND EARLY HISTORY OF THE PRIMORDIAL GERM-CELLS IN THE CHICK
}

\author{
CHARLES H. SWIFT \\ From the Hull Laboratory of Anatomy, University of Chicago \\ FIFTEEN FIGURES \\ CONTENTS \\ Introduction and review of the literature $\ldots \ldots \ldots \ldots \ldots \ldots \ldots \ldots \ldots . \ldots 48$ \\ Material and methods ..................................... 489 \\ Origin and history of the primordial germ-cells .................. 491 \\ 1. Structure of the germ-cells.............................. 491

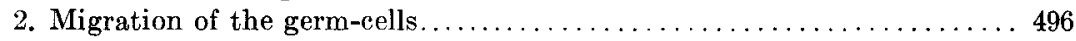 \\ 3 . Origin of the germ-cells............................... 510

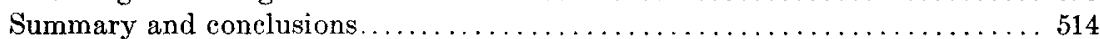 \\ Bibliography......................................... 515
}

\section{INTRODUCTION AND REVIEW OF THE LITERATURE}

There are several theories held as to the origin of primordial germ-cells. The theory that they arise from a differentiated portion of the coelomic epithelium over the Wolffian body has priority and should be mentioned first. Waldeyer ('70) was the first to advance this idea as to an origin from a so-called germinal epithelium. His opinion advanced in the work "Eierstock und Ei," remained unchallenged for a long time. It has had a number of supporters, and even at the present day, the theory that the primordial germ-cells arise in the germinal epithelium, is the only one found in a majority of text-books. That this theory should have a long life is only natural. The early investigators did not possess the finished methods or perfected instruments of today and so were placed at a serious disadvantage when working with the younger stages. Also, as we now know, the germ cells in the earlier stages of development, are not grouped, but may be widely scattered, and for this reason, if for no other, they 
would be much more difficult of demonstration than when collected into a relatively circumscribed area like the germinal epithelium or developing gonad. In the older embryos, however, they were able to see the typical primordial germ-cells in the modified coelomic epithelium, and so naturally thought that they arose by a series of transformations from the epithelial cells. Semon ('87) claimed to have seen a number of cells undergoing this change of form, but since that time no other investigator has ever been able to see any intermediate stages between the cells of the germinal epithelium and the primordial germ-cells. D'Hollander ('04) described in the chick embryo of ten days, however, the production of oogonia from a superficial indifferent layer of cells-another term for germinal epithelium. According to d'Hollander, the germinal epithelium gives rise to epithelial buds, which grow down into the ovarian stroma. From these epithelial, germinative buds, by a process of differentiation, the oogonia and primordial follicular cells arise. This origin of oogonia at such a late period and from the germinal epithelium must be secondary to the production of primordial germ-cells, which, according to all authorities, make their appearance in the gonad at a much earlier period of development than ten days.

Another view as to the origin of primordial germ-cells may be called the gonotome theory. The supporters of this theory agree with the advocates of the germinal epithelium origin in so far that the primordial germ-cells are found at one time in the modified coelomic epithelium. They, however, claim that the primordial germ-cells do not arise in the germinal epithelium, but from a portion of the segmental mesoderm, and reach the epithelium at a later period either by migration or by tissue growth. Rückert ('88) advanced this idea, and called that portion of the segmental mesoderm, from which he supposed they took origin, the gonotome. That certain of the primordial germ-cells are, at times, found in the region of the segmental mesoderm there can be no doubt, but, their occurrence there can be explained in another and better way than by supposing that they take origin there. This theory has had few advocates, and is of importance now, mainly because of the historical interest attached to it. 
The supporters of the third theory, that of early segregation, agree with the exponents of the other two, that the primordial germ-cells are at one time in their history found in the germinal epithelium. They do not, however, believe that they arise in situ, nor from the gonotome, but that they have a much longer history dating back to an early embryonic stage. It may be possible, at some future time, to trace the primordial germ-cells back to the very early divisions of the segmenting egg, if not to the fertilized egg itself. In vertebrates, the work of Eigenmann ('97), demonstrated an origin of primordial germ-cells within five divisions of the fertilized egg; that is, he found that the youngest germ-cells possessed a size equivalent to blastomeres of the fifth cleavage. If this last is correct, that the germ-cells have an independent existence from a very early period, and are not differentiated from somatic cells, then the idea of germ-plasm continuity has received valuable support. This idea of early and extraregional origin is borne out by all recent research, and is becoming more firmly established with each succeeding year.

The names of Hoffmann ('93) Eigenmann ('97), Nussbaum ('01) and Beard ('04) are associated with the early years of this early segregation theory of germ-cell origin.

Hoffman ('93) was the first to bring forward any evidence which cast doubt on the theory of origin of primordial germcells from the germinal epithelium. He employed in his work twelve species of birds, in three of which, Haematopus ostralegus, Sterna paradisea, and Gallinula chloropus, there was sufficient evidence brought out to prove that some, if not all the primordial germ-cells, did not originate in the modified coelomic epithelium. In the three species mentioned above, he found at the proper time, numbers of primordial ova in the germinal epithelium. But, in addition he found cells-supposedly primordial ova, because of their resemblance to those found later in the germinal epithelium-in embryos of 23 somites. An embryo of 23 somites does not possess the so-called germinal epithelium, the coelomic epithelium over the Wolffian body not having been modified at this age, yet in these he found primordial germ-cells far removed from the site of the future sex-gland, in the splanchnic 
plate of mesoderm, in the region between splanchnic mesoderm and entoderm and in the entoderm.

Eigenmann ('97) was one of the first to prove that primordial germ-cells may have an extra-regional origin. His work on the viviparous teleost Cymatogaster showed that the primordial germcells in that form, have an origin from cells having the size of fifth cleavage blastomeres.

Beard ('04) discovered in Raja batis that the primordial germcells have an origin from a group of cells in the anterior part of the blastoderm, beneath the embryonic anlage, and that these cells then migrate in towards the region of the future sex-glands along a very definite path, through the hypoblast of the gut and the line between hypoblast and unsegmented splanchnic mesoderm. These early extra-embryonic germ-cells, which he called megaspheres, differ in no particular, except size, from the germcells, which are found in the older embryos.

Nussbaum ('01), Rubaschkin ('07), and von Berenberg-Gossler ('12), in addition to Hoffmann ('93) have investigated the primordial germ-cells in bird embryos. The first three worked with the chick and were able to find in embryos of 22 to 23 somites typical germ-cells in the entoderm and splanchnic mesoderm lateral to the coelomic angle, some of which in older embryos passed into the germinal epithelium. The 22-somite embryo is the youngest in which primordial germ-cells have been found in the chick.

Allen ('06), ('09), ('09), investigated this question of primordial germ-cell origin in Chrysemys, Amia and Lepidosteus and discovered that the primordial germ-cells in these forms had an entodermal origin, in the case of Chrysemys from the entoderm near the margin of the area pellucida in a zone extending on either side from the anterior extremity of the pronephros to a point behind the embryo. The primordial germ-cells of Lepidosteus have a not very different origin, while in Amia they were shown to come from the entoderm of the roof and margin of the floor of the sub-germinal cavity.

Allen has shown that in these forms there is a definite migration. In the youngest embryos the primordial germ-cells have 
an amoeboid form and a lateral position in the hypoblast; in older stages these cells still have an amoeboid form, but have a more median position, which they have attained by a centripetal movement along the hypoblast. In the still older embryos these cells are found to have lost their amoeboid character and to be in the entoderm under the notochord or in the mesoderm in that immediate neighborhood. Thence, according to the evidence of the still older embryos, they pass into the mesentery and finally assume a position which corresponds to that of the future sexgland.

Woods ('02), working on Acanthias, found that the primordial germ-cells were first evident in the entoderm and in the periblast and thence migrated to the sex-gland anlage.

Jarvis ('08), in Phrynosoma, found that the germ-cells appeared first in the entoderm of the vascular area of the blastoderm, where they were cephalad, caudad, and laterad to the embryo. Then by a definite migration path they reached the germinal anlage.

Dodds ('10), investigating the question of germ origin and history in the teleost, Lophius, was able to recognize the primordial germ-cells in the primitive entoblast, when the blastoderm had not quite half covered the yolk. He, however, believed that they were set apart at a time earlier still in embryonic history.

Finally, as far as vertebrates are concerned, Fuss ('11), in a human embryo of four weeks, with about 33 somites, demonstrated extra-regional primordial germ-cells in the mesentery directly under the coelomic epithelium.

Among invertebrates, in many phyla, the primordial germcells have been observed at a distance from the site of the future sex-gland, that is, in an extra-regional position, and in several cases have been traced back to their true origin. Indeed, Balbiani's ('85) 'work with Chironomus was one of the very earliest in which a definite origin was proven for the primordial germcells. He found that they originated from cells differentiated very early in the history of the segmenting egg.

The most remarkable known case of early differentiation of the primordial germ-cells is that of Ascaris, in which Boveri 
('92) was able to follow them back directly through all the cleavage stages to the two-cell stage.

Haecker ('97), in Cyclops, and Hegner ('09), in some Chrysomelid beetles, were able also to trace the primordial germ-cells back to early segmentation stages.

It may be said, then, that in many groups of vertebrates, as well as invertebrates, all the primordial germ-cells do not originate in a differentiated portion of the coelomic epithelium called the germinal epithelium. In many of the cases cited the exact origin of the primordial germ-cells has not been found, but even in these it has been definitely established that the germ-cells arise in the early history of the embryo long before the appearance of a germinal epithelium. So, with the evidence at hand, it would seem that Nussbaum was correct when in 1880 he formulated the hypothesis that "the sexual cells do not come from any cells that have given up their embryonic character or have gone into building any part of the body, nor do sexual cells ever go into body formation."

The bird groups still offer an excellent opportunity for research into the history of the primordial germ-cells, for, notwithstanding the amount of work which has been done by Nussbaum, Hoffmann, Rubaschkin, von Berenberg-Gossler, and others, the origin of the primordial germ-cells still remains unrevealed. The stage of 22 or 23 somites is the youngest in which germ-cells have been described among birds.

In carrying out this research $I$ have received constant aid and advice from Prof. R. R. Bensley. I wish to thank him for this. as well as for a training which has made possible whatever in my results may be considered of value. I also wish to thank Dr. E. V. Cowdry and Dr. G. W. Bartelmez for their assistance as. well as kindness in allowing me to use their excellent preparations. I am also indebted to $\mathrm{Mr}$. A. B. Streedain for the drawings which illustrate this article. 


\section{MATERIAL AND METHODS}

In the selection of a fixative for the germ-cells, the yolk material, mitochondria, and attraction-sphere, in addition to the nucleus and general cytoplasm, have to be taken into consideration. The same fixing fluid cannot be relied upon in all stages, but in order to meet the changing cell content, a variation is necessary. For instance, the yolk-laden germ-cell of the very young embryos requires very different treatment from the almost yolk-free cell of the later stages, if equally good results in both cases are desired. So that in the case of embryos over 20 somites in development, in which the germ-cells contain only a moderate amount of the primary vitellus, a fixing fluid containing osmic acid may be used to advantage. Osmic acid resembles potassium bi-chromate, with which it is frequently combined, in being an excellent cytoplasmic preservative. It has its drawbacks, however, in being a poor penetrant, amd in blackening the yolk of the germcells. This last property of osmic acid is a decided disadvantage in the early stages, in which the cytoplasm of the germ-cells is stuffed with yolk spheres, and an advantage in the case of the older embryos, in which the yolk is reduced in amount, since the blackening of the vitellus facilitates identification.

Fixatives such as Benda's, Meves' modification of Flemming's fluid, and Bensley's acetic-osmic-bichromate mixture, all of which contain osmic acid, were found to be best adapted for use in the case of older embryos, in which there is little yolk material remaining. They preserve such cytoplasmic structures as mitochondria and the attraction-sphere excellently, and, thanks to their osmic acid content, bring out the yolk spheres plainly. However, in the younger embryos, from the primitive streak stage to 20 somites, they were found to be not nearly so efficient. In these stages the yolk content of the germ-cells is so great that the value of any fixative containing osmic acid is seriously diminished. In these young embryos a mixture of equal parts of 5 per cent trichloracetic acid and 5 per cent sublimate was found to be excellent. The mitochondria are not preserved by this 
method, but the obscuring of the nucleus and cytoplasm by the large, blackened yolk spheres is avoided.

An ideal fixing fluid should not only be an excellent cytoplasmic preservative but should also have the ability to penetrate rapidly. Unfortunately osmic acid and potassium bichromate are lacking in this last quality. Acetic acid is frequently combined with them because of its penetrating powers. However, too much acetic acid is worse than none at all, since cytoplasm and its contained organs, like mitochondria, are very sensitive to this agent. For this reason Zenker's fluid is of no value in the preservation of mitochondria. The acetic-osmic-bichromate mixture of Bensley contains these fixing agents in about the proper proportions, and yet even this leaves something to be desired. It is of value as a fixative only when small pieces are used. It really preserves, as in the natural state, only the outer surface of a piece of tissue. In the center of a block of any size the mitochondria are found to be globular, instead of rod-like, or even to have disappeared altogether. The value of the acetic-osmicbichromate mixture depends upon all the elements in it. They do not all penetrate with equal speed; the acetic acid is much the more rapid in this regard. Near the periphery of a piece of tissue they act in unison, as is intended, but the acetic acid soon forges ahead and acts in an injurious manner upon the cytoplasm and especially upon the mitochondria,

The following staining methods were employed. Following the Benda fixaton the Benda staining method was used. This procedure is the one commonly employed for demonstrating mitochondria. It was first published by Benda in 1901 .

Following Bensley's acetic-osmic-bichromate mixture two general staining methods were used, namely, the anilin acid fuchsinmethyl green method and Bensley's copper-chrome-hematoxylin technique. There were, however, several modifications of the first. In place of methyl green as a counterstain, toluidin blue or Wright's blood stain may be substituted. Bensley ('11) described these methods in detail, so there is no need to recapitulate here. 
All these procedures are reliable and a beautiful result is usually obtained, especially at the periphery of a section.

Following Meves' modification of Flemming's fluid the ironhematoxylin stain was employed. This method was found to be more reliable in the moderately young embryos -15 somites to 25 somites - than the acetic-osmic-bichromate method.

After the 5 per cent trichloracetic acid and 5 per cent sublimate fixation iron-hematoxylin and acid fuchsin gave excellent results. The cytoplasm is well preserved and the attractionsphere especially so. The centrosomes were more frequently seen after this procedure than after any other.

In all cases where embryos of relatively advanced age were employed, the anterior body wall, amnion and viscera were removed, thus exposing directly to the fixative the Wolffian body and gonad. All sections were cut 4 micra thick.

Table 1 will show at a glance the number of embryos employed, their age, together with the methods used in fixation and staining.

\section{ORIGIN AND HISTORY OF THE PRIMORDIAL GERM-CELLS}

\section{Structure of the germ-cells}

It will be better to describe the form and structure of the primordial germ-cells in the chick before proceeding to a description of their origin and history. In this way the necessity of describing them with each stage of development will be avoided. There is all the more reason for this since more than one portrayal of them would be a repetition. The change in the germ-cells, from their origin to the time when they pass into the indifferent gonad, is limited to one or two structures. These variations will be taken up at the stage of development at which they appear most evident.

Size and shape. The most noticeable attributes of these primordial germ-cells, the characters, which first attract attention in examining a section containing them, are their size and shape. Isolated in the general mesenchymal tissue they appear immense (figs. 2 and 8). Their size, which is much greater than that of 


\begin{tabular}{|c|c|c|c|c|c|c|}
\hline$\frac{c}{b} \sin v a$ & & & o & 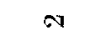 & & \\
\hline $88 \cdot \mathrm{s}$ & & $\alpha$ & & & & \\
\hline$z 8 \cdot \mathrm{s}$ & & $\sim$ & & & & \\
\hline $18 \cdot 8$ & $-r$ & & & & & \\
\hline $08 \cdot s$ & $\rightarrow$ & & & & & \\
\hline $6 z \cdot 8$ & $\rightarrow$ & & & & & \\
\hline $86^{\circ} \mathrm{s}$ & -1 & & & & & \\
\hline $28 \cdot \mathrm{s}$ & - & & & & -1 & \\
\hline $98 \cdot 8$ & $-r$ & & & & - & \\
\hline$\$ z \cdot s$ & $\hookrightarrow$ & & & & - & \\
\hline $\pm 2 \cdot 8$ & -1 & & & & - & \\
\hline $8 z \cdot s$ & $\rightarrow$ & & & & & \\
\hline$\pi 8 \cdot s$ & -1 & & & & & \\
\hline Iz $\cdot 8$ & 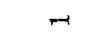 & & & & - & \\
\hline $06 \cdot \mathrm{s}$ & - & & & & & \\
\hline $6 \mathrm{I} \cdot \mathrm{s}$ & $\infty$ & & & & & \\
\hline $8 I \times$ & $\infty$ & & & & & \\
\hline $2 I \cdot 8$ & $\mathrm{~N}$ & & & & & \\
\hline $9 \mathrm{I} \cdot \mathrm{s}$ & -1 & & & & & \\
\hline $2 \mathrm{I} \cdot \mathrm{s}$ & -1 & & & & & \\
\hline of 18 & $\rightarrow$ & & & & & \\
\hline $6 \cdot s$ & -1 & & & & & \\
\hline $9 \cdot 3$ & -1 & & & & & \\
\hline 8 STu:KOOS & - & & & & & $\rightarrow$ \\
\hline 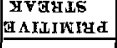 & $\infty$ & & & & & -1 \\
\hline \multirow[t]{2}{*}{$\begin{array}{l}\stackrel{8}{8} \\
\text { 曽 }\end{array}$} & \multirow[t]{2}{*}{ 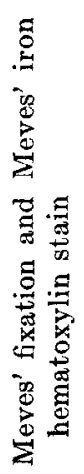 } & 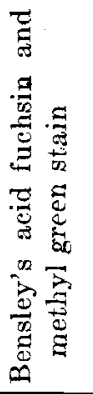 & 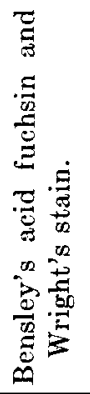 & 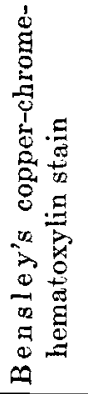 & \multirow[t]{2}{*}{ 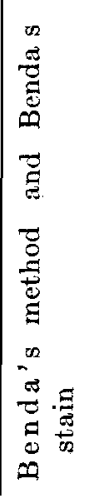 } & \multirow[t]{2}{*}{ 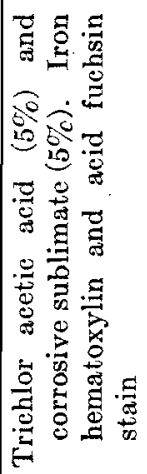 } \\
\hline & & 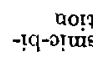 & : & प्रव & & \\
\hline
\end{tabular}


the neighboring cells, is due to an increase in volume of both nucleus and cytoplasm. Their shape also is different from that of the surrounding cells. The latter are frequently stellate, although they may be round, oval, flattened, or elongated, while the germ-cells are always round or oval (figs. 2, 6, and 10). The germ-cells have an average diameter of about 16 micra. They may have a diameter as small as 14 micra, while in exceptional cases this may reach 20 or even 22 micra.

Nucleus. The large nucleus, which has a diameter of 8 to 12 micra, is spherical and vesicular, and is nearly always eccentrically placed (figs. 7, 8 and 13). It is surrounded by a definite nuclear membrane. On comparing the nuclei of the primordial germ-cells, with those of the neighboring cells, in addition to the disparity in size, it is noticed that the germ-cell nuclei are clearer. The germ-cell nuclei seem to contain about the same amount of chromatin as the nuclei of neighboring cells, but owing to the increase in size of the former it appears greatly reduced in amount. The germ-cell nucleus, at one pole, is separated from the cell membrane by a thin layer of cytoplasm, while the attraction sphere generally occupies the other pole, where a wider expanse of cytoplasm separates the nucleus from the membrane. The clear appearance of the nucleus of the germ-cell is not confined to the chick alone but is common to many species.

The chromatin within the nucleus generally has a definite arrangement, being grouped in two masses (figs. 2, 4, and 8). This holds in nearly all stages except the youngest where the chromatin has the appearance of a reticulum. The chromatin in the two masses, mentioned above, appears in the granular form. The two masses themselves may be quite distinct, being separated by a wide clear interval, or they may approach each other closely. In some cases they are connected by granular threads. This definite arrangement of the chromatin does not appear after one fixation only, but can be observed after acetic-osmic-bichromate, equal parts of 5 per cent trichloracetic acid and 5 per cent sublimate as well as Meves' modification of Flemming's fluid.

The attraction-sphere. The attraction sphere is the most characteristic organ of the primordial germ-cell in the chick, and, 
oddly enough, its importance has been overlooked by all workers except Rubaschkin ('08) and von Berenberg-Gossler ('12). It is present in all stages, and, from the origin of the germ-cell to its entrance into the indifferent gonad, does not undergo any change. It appears as a condensed or flattened sphere of cytoplasm resting usually on the nuclear membrane, on that side of the nucleus, which is the farthest removed from the cell membrane (figs. 2, 5 and 9). It may rest on the nuclear membrane directly, in which case, it has a concavity towards the nucleus, or it may be separated from the nucleus by some distance. It has an average diameter of 3 to 4 micra, but in some cases where it is flattened against the nucleus, its long axis may measure 6 micra. At times it is very discrete and seems to be surrounded by a definite membrane. The cytoplasm immediately around it appears less dense than the rest, so that the attraction-sphere seems to be situated in a vacuole. In all stages and with all stains the sphere is prominent and unless obscured by yolk spheres is easily seen.

The centrosomes are best seen after trichloracetic acid fixation and iron-hematoxylin staining, when they appear as black dots. With this fixation cytoplasmic radiations may be observed radiating out from the attraction sphere.

Attraction-spheres are, of course, not confined to the primordial germ-cells, but in the other cells they are not nearly so large, distinct or constant as in the germ-cells. Because of its size, discreteness and constancy, it serves as the best criterion for identification of germ-cells in the chick.

Yolk. Yolk material is a very characteristic constituent of the primordial germ-cells in the chick. Its abundance in the young stages has been recorded by Nussbaum ('01), Rubaschkin ('08) and von Berenberg-Gossler ('12). The very young germcells, just after their origin, are simply loaded with the yolk which has the form of spheres; the cytoplasm is so crowded that practically nothing but yolk can be seen (figs. 12 and 14). Most abundant in the younger germ-cells, it gradually decreases in amount as the embryo increases in age. In embryos having about 20 somites and thereafter, there is a great variation in the quantity of yolk in the germ-cells. In some embryos the germ- 
cells may all have no yolk, while in others, some will have yolk while the remainder will have none at all.

In the embryos of moderate age -20 to 26 somites - there is evidence that the yolk is undergoing digestion, as is shown by the fact that in the same primordial germ-cell fixed with osmic acid some of the yolk spheres will be intensely black while others will be brown or yellowish. The yolk spheres which are not black in these cells are frequently surrounded by a clear ring.

In the embryos of about 20 to 26 somites, the yolk spheres reach their greatest size (fig. 7 ). In one case one had a diameter of 8 micra. In the younger germ-cells the yolk spheres are smaller having an average diameter of 2 to 3 micra. In embryos with 33 somites to four and one-half days the yolk content varies a great deal; usually there is only a small quantity present, which is confined to 5 to 10 small spheres, which usually show signs of digestion.

In the very young primordial germ-cells the yolk is scattered evenly throughout the germ-cell, usually entirely surrounding the nucleus, which may have a central rather than an eccentric position. As the germ-cell grows older the yolk diminishes in amount and retreats to one side of the nucleus, usually the cell pole which is occupied by the attraction-sphere (figs. 7 and 9). As the yolk decreases still more in amount it is confined to the region between the attraction-sphere and the cell membrane. At this stage the yolk spheres are apt to be arranged in a horseshoe shaped manner, with the concavity turned towards the attraction-sphere (fig. 6).

The yolk remains in the primordial germ-cells long after it has disappeared from the tissue cells. The presence of the yolk in the germ-cells is probably related to the absence of mitoses in these cells.

Mitochondria. The mitochondria in the primordial germ-cells of the chick are not at all characteristic. They resemble the mitochondria of the somatic cells (figs. 5, 8 and 11), and at the same time retain the same appearance, whether in the primitive streak stage or four and one-half day chick. They are seen usually to be in the form of short rods of a length varying from 1 to 
3 micra. These rod-like mitochondria do not as a rule have a homogenous structure, but are beaded or granular rods; that is, beads or granules closely approximated and arranged in a row or rod. At the same time in all stages discrete granules may be present, but they are never seen to the exclusion of the rod form unless the fixation has been faulty.

This is at variance with the work of Rubaschkin ('10) and Tschaschin ('10), who found, the former in mammals and the latter in birds, that the primordial germ-cells are characterized by granular mitochondria, while those of the somatic cells are rodlike in character.

Size of the primordial germ-cell, nucleus and attraction-sphere. The size of the germ-cell varies little, if any, from its origin, to its entrance into the indifferent gonad. The average diameter of nearly every one is found between the figures 14 and 18 micra. The majority approach the larger figures.

The nucleus undergoes a little variation in size. That of the germ-cells of the primitive streak stage to 9 somites has a diameter of 8 to 10 micra. In germ-cells of embryos possessing more than 12 somites the nuclear diameter varies between 10 to 12 micra.

The attraction-sphere has a constant long diameter of 3 to 4 micra. This relatively constant size of the primordial germ-cell, and of its organs, the nucleus and attraction-sphere, together with the retention of yolk, after its disappearance from the somatic cells, may be taken as an evidence that the germ-cells do not divide during their migration history.

\section{Migration of the germ-cells}

In investigating the history of the primordial germ-cells of the chick it was found to be expedient to commence the study on older embryos. The advantages of this method of study are obvious; the older embryos are larger and therefore much easier to handle than the younger ones, and in addition the germ-cells have been observed down to embryos of about 22 somites and described and studied by several able investigators -notably Hoffman ('93), Nussbaum ('01), Rubaschkin ('07), Tschaschin ('10) and von Berenberg-Gossler ('12). Therefore, in begin- 
ning with these older forms, one can become familiar with the germ-cells in regions where they have been seen and studied before, and acquire a more perfect technique, before following them back through an unknown migration to an equally unknown and obscure origin.

In an embryo of four and one-half days incubation the germinal epithelium is found to be developed along the medial surface of the Wolffian body. It is composed of cells which differ from those of the general coelomic epithelium in being cuboidal or columnar. Owing to the greater height of these cells a ridgelike appearance is produced on the medial surface of the Wolffian body, which may simulate a developing gonad. The gonad itself is forming only at the level of the anterior half of the Wolffian body, where stroma is beginning to appear beneath the germinal epithelium. The developing mesentery, springing from between the Wolffian bodies, has attained a length easily appreciated by the unaided eye.

Scattered here and there in the stroma of the developing gonad, in the root of the mesentery, both in the mesenchymal tissue and in the coelomic epithelium near the coelomic angle, and in the germinal epithelium, clothing the gonad, are certain cells which are sharply marked off from the neighboring cells. They are the primordial germ-cells which have previously been described in this article, and which have been noticed and studied at this stage and this region by all investigators of germ-cell history in the chick since the publication of Waldeyer's "Eierstock und Ei."

By far the greater number of the primordial germ-cells in the four and one-half day embryo are found in the gonad, and in the root of the mesentery near the coelomic angle, but some are to be seen in other situations, namely, in the mesentery at a distance from its point of attachment to the body, in the wall of the gut, in the mesenchyme behind the aorta and in front of the notochord and even an occasional one dorsal and lateral to the notochord.

The germinal epithelium in the chick of four and one-half days of incubation is well developed. It consists of a strip of cuboidal to columnar cells, without any basement membrane, which on 
either side merge into the flatter cells of the general coelomic epithelium. Scattered among the germinal epithelial cells an ocasional primordial germ-cell is to be seen. In observing these cells the question naturally arises as to whether they have arisen in situ or have reached that position through a migration after having originated elsewhere. Waldeyer ('70), it will be remembered, formulated, the former idea. The researches of Hoffman ('93), Nussbaum ('01), Rubaschkin ('07), and others have cast rather serious doubts upon the correctness of this theory. In fact it may be said to have been disproven as regards some of the germ-cells. The fact that typical germ-cells are found in the root of the mesentery and in the coelomic epithelium before the differentiation of a portion of the coelomic epithelium into germinal epithelium certainly is proof enough that some of them at least do not arise there. However, the origin of some of the germ-cells from the germinal epithelium has never been positively dispproven. Semon ('87) in supporting Waldeyer's ('70) idea, claims to have seen transitions between cells of the germinal epithelium and primordial germ-cells. In that case, in these chick embryos fixed after an incubation of four and one-half days, one would expect to see certain of the epithelial cells with the large attraction-sphere which is so constant and characteristic of the primordial germ-cells. Also, it would naturally be expected that some of them should possess yolk granules, and the large vesicular nucleus and typical chromatin arrangement, while yet possessing the moderate size and cuboidal shape, which is typical of the epithelial cells. On the contrary, however, there seem to be no cells present which could in any way be classed as intermediate between the germinal epithelial cells and the true primordial germ-cells. They are all either germ-cells or epithelial cells, and, as far as the four and one-half day chick is concerned, one is forced to the conclusion, either that the germ-cells in the germinal epithelium do not arise in situ but reach that position through tissue growth or migration, or, if any have arisen there through a transformation, it occurred at an earlier stage. All recent investigation seems to favor the former alternative. 
In chick embryos possessing 31 to 33 pairs of somites, the gonad has not commenced to develop, nor has the germinal epithelium been differentiated, as yet, from the coelomic epithelium. At this stage the primordial germ-cells are found in the root of the forming mesentery, in the coelomic epithelium, in the neighborhood of the coelomic angle, and, in the medial and posterior

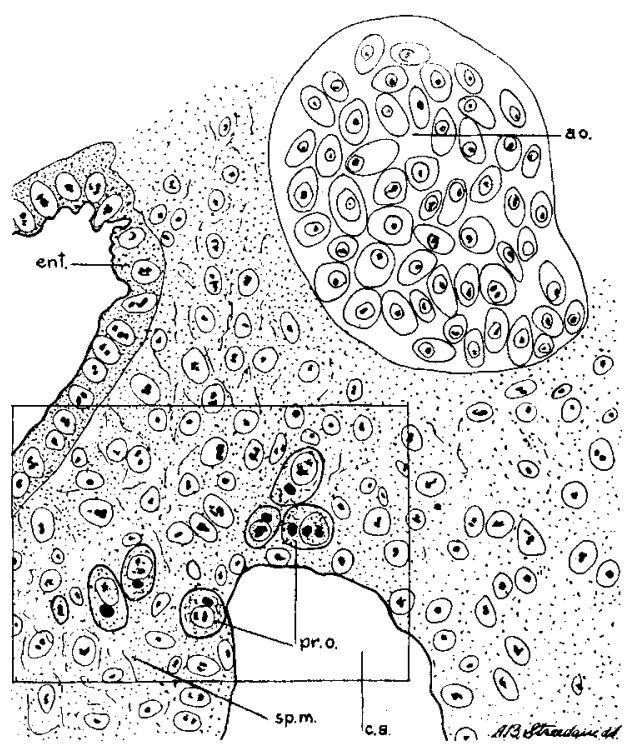

Fig. 1. Portion of a transverse section through the twenty-second somite of a 33 somite embryo; same embryo as figure 2, for which this figure is the key-plate. Benslcy's acetic-osmic-bichromate fixation and Bensley's anilin acid fuchsinWright's stain. $\times 120$. This figure is intended to give an idea as to the usual position of the primordial germ-cells in the 33 somite chick. pr.o., primordial germ-cells; ent., entoderm; sp.m., splanchnic plate of mesoderm; ao., aorta; c.a. coelomic angle.

region of the splanchnic plate of mesoderm, just where it is passing into the developing mesentery (fig. 1). The vast majority of the germ-cells are found in these regions, but an occasional one is located elsewhere; far out in the splanchnic mesoderm, and at times in a more dorsal situation in the loose tissue around the aortae. 
The primordial germ-cells, at the stage of 31 to 33 somites, are frequenty found in groups of three or four, and are typical germcells in all respects (fig. 2). Only two facts relating to them are worthy of special attention. The yolk material found in them is subject to great variation and is undergoing some change, which is evidenced by the varying reaction to the osmic acid and stain. In some germ-cells the yolk is black, in others brown or yellow, while in others it is stained by the dye used rather than the fixing agent. In some cases all these changes are shown in a single germ-cell. The yolk material is probably being used up in cell metabolism, or being transported elsewhere.

The amoeboid appearance of the primordial germ-cells at this stage is also worthy of mention. This property was not evident in the germ-cells of the four and one-half day chick, owing to the fact that active migration had ceased. However, the germcells at 31 to 33 somites are highly amoeboid. Nearly all possess an oval shape, while many are drawn out into a tapering process, which extends between the somatic cells. This process is single and is usually on the side of the cell opposite to the attraction-sphere.

Embryos with 29 and 26 pairs of somites may be classed together, since there is no difference worthy of mention as far as the position of the germ-cells is concerned. In these embryos of this age the primordial germ-cells are found in the splanchnic mesoderm at no great distance from the point where splanchnopleure and somatopleure become continuous, that is, near the coelomic angle. In the embryo possessing 29 somites 110 germcells were counted. Of this number the vast majority (98) were found to be in the splanchnic mesoderm while only 12 were counted in the somatopleuric side of the angle of the coelom.

The primordial germ-cells in both these embryos are present either in the mesodermal portion of the splanchnopleure or between the mesoderm and entoderm. In not a single instance is one to be seen in the entoderm. The germ-cells are usually found singly, although, as was mentioned before, they may occur in groups of two to four. They are all situated behind the level of the 20th mesoblastic somite. 
The next embryo to be studied possesses 25 pairs of somites and an approximate age of forty-four hours.

Down to this point the situation in which the primordial germcells are found agrees with that given by all who have done any investigation on this subject. Hoffman ('93) and, in fact, all who have worked upon the subject of primordial germ-cell history in the chick, have described the indifferent gonad and the presence of the sex-cells in the splanchnic mesoderm. No one,

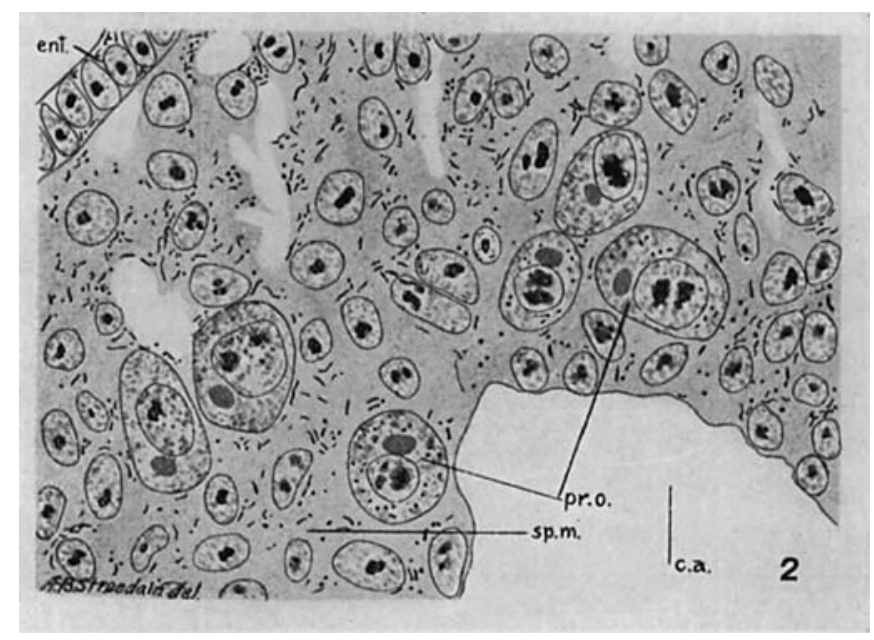

Fig. 2 Portion of a transverse section through the twenty-second somite of a 33 somite embryo; this figure is drawn from the same embryo as figure 1. Bensley's acetic-osmic-bichromate fixation and Bensley's anilin acid fuchsin-Wright's stain. $\times 787$. This figure shows the position, form and grouping of the primordial germ-cells in the 33 somite chick embryo. pr.o., primordial germ-cells; ent., entoderm; sp.m., splanchnic plate of mesoderm; c.a., coclomic angle.

however, has been able to trace them back to a stage earlier than that of 22 somites. This inability to find them in younger embryos is surprising but nevertheless can be explained. The students of germ-cell history and migration in the chick have, no doubt, had constantly in mind the work of Beard, Allen, Woods and Jarvis, who investigated this question in forms, in which a definite migration occurred through the entoderm or splanchnic mesoderm. They have expected this same kind of migration to 
occur in the chick, and, therefore, have studied with care the entoderm and splanchnic mesoderm, and in so doing have neglected the key to the situation, the blood vessels.

The embryo with 25 somites may be called a transition stage, for the primordial germ-cells are present both in the blood vessels (figs. 3 and 4) and in the splanchnic mesoderm. The embryo with 21 somites may also be placed in this category. Were it not for the presence of primordial germ-cells in the blood vessels, this embryo with 25 somites could be passed over rapidly, because the position of those in the tissues coincides exactly with their situation in the older embryos. That is to say, they are found in the splanchnic mesoderm near its junction with the somatic mesoderm at the coelomic angle.

In the blood vessels the primordial germ-cells are found in two situations, in the small vessels of the medial portion of the splanchnic mesoderm (figs. 3 and 4) caudad to the 19th somite in certain vessels of the head (fig. 5).

The primordial germ-cells found in the latter situation--that is, in the vessels of the head region of this 25 somite embryoare remarkably disposed. Twelve embryos of about this agebetween 22 and 29 somites - were examined, yet in only one, that possessing 25 somites, were the germ-cells massed. And, indeed, in no embryo studied was a like condition encountered. The arrangement, then, of the germ-cells is probably abnormal, but nevertheless, merits a description. The germ cells are present in the radicles of the anterior cardinal veins (fig. 5). In this region, as was mentioned before, the germ cells are not found singly as in the vessels of the splanchnic mesoderm, but in masses or lumps. These masses are four in number; a large group on either side of the forebrain and two smaller groups. These collections of germ-cells seem to entirely occlude the vessels in which they are contained and remind one of emboli (fig. 5). Mixed in with the germ-cells are the smaller blood cells (fig. 5). In one of the large groups four of the germ-cells are dividing; this presence of mitotic figures is worthy of notice, since in only one primordial germ-cell (fig. 10), these excepted, was division observed, from their origin until they pass into the gonad. To 

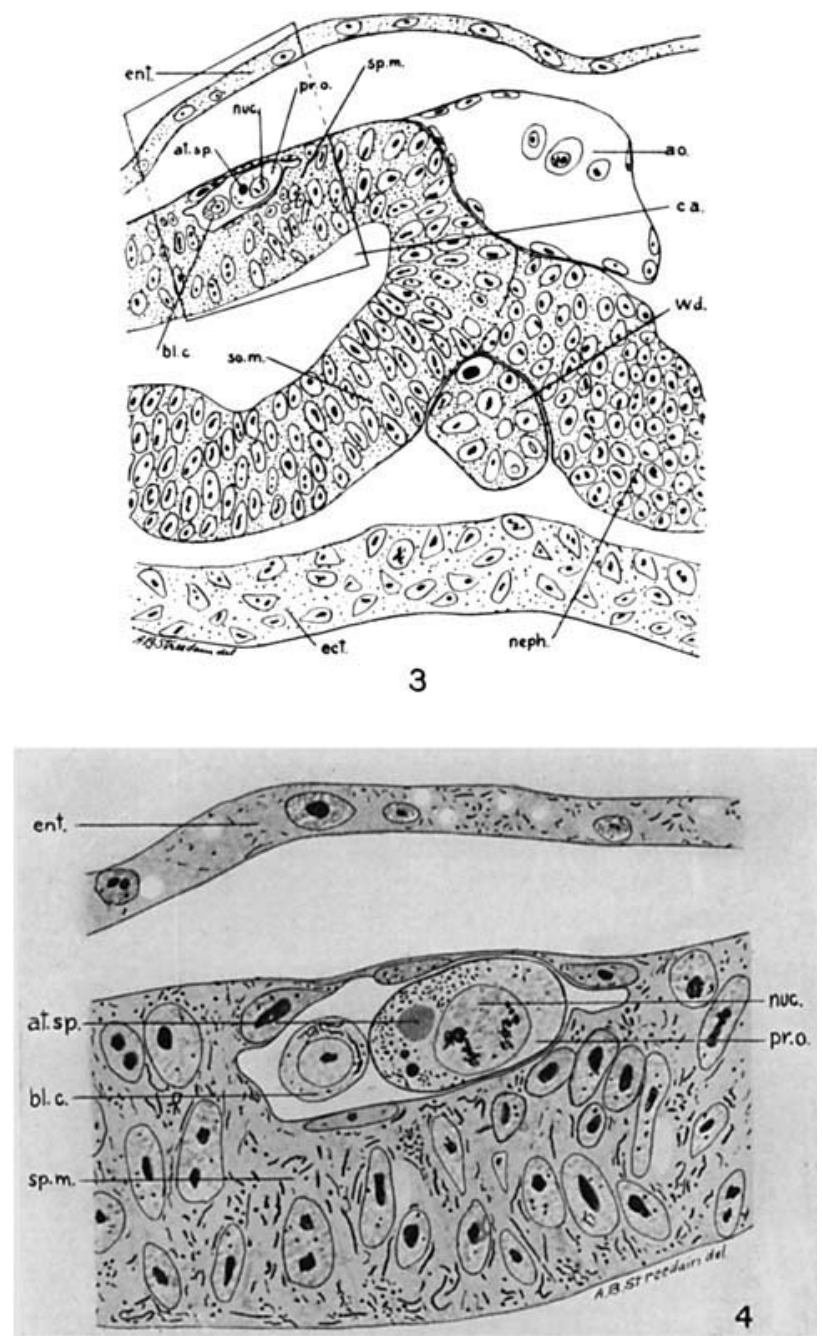

Fig. 3 Portion of a transverse section through the twentieth somite of a 25 somite embryo; same embryo as figure 4, for which this figure is the key-plate. Meves' fixation and Meves' iron-hematoxylin stain. $\times 120$. pro., primordial germ-cell in small blood vessel of splanchnic mesoderm; nuc., nucleus of primordial germ-cell; at.sp., attraction-sphere of primordial germ-cell; bl.c., blood cell in blood vessel; sp.m., splanchnic layer of mesoderm; so.m., somatic layer of mesoderm; ao., aorta; ent., entoderm; ect., ectoderm; Wd., Wolffian duct; neph., nephrotome.

Fig. 4 Portion of a transverse section through the twentieth somite of a 25 somite embryo; this figure is drawn from the same embryo as figure 3 and is a higher magnification of the marked off region. Meves' fixation and Meves' iron-hematoxylin stain. $\times 1125 . \quad$ pr.o., primordial germ-cell; nuc., nucleus of germ-cell; at.sp., attraction-sphere of germ-cell containing a centrosome; bl.c., blood-cell; ent., entoderm; sp.m., splanchnic mesoderm. 


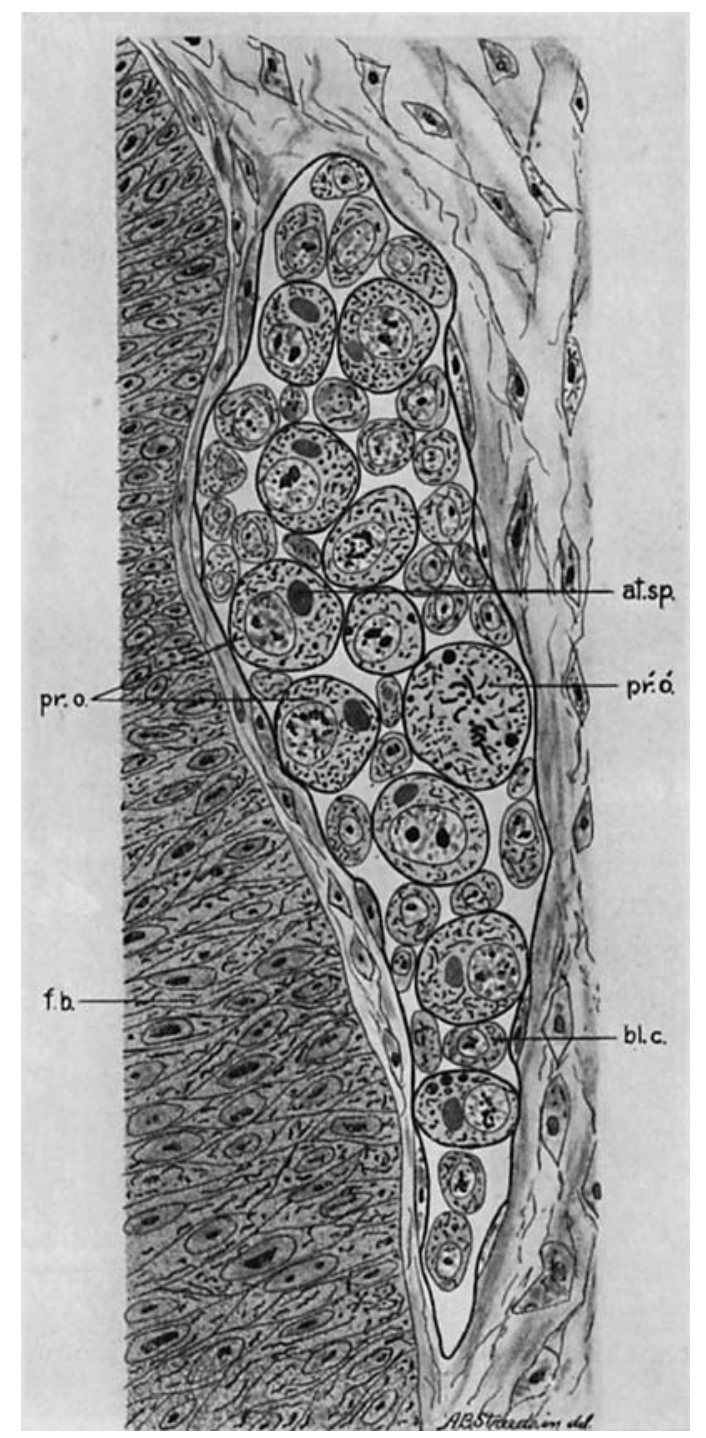

Fig. 5 Portion of a transverse section through the head region of an embryo with 25 somites. Meves' fixation and Meves' iron-hematoxylin stain. $\times 787$. pr.o., primordial germ-cell; $p r . o^{\prime}$. , primordial germ-cell dividing; at.sp., attractionsphere of germ-cell; bl.c., blood cell; $f . b$., fore-brain. 
repeat, then, this massing of the primordial germ-cells in the vessels is something out of the ordinary for no evidence of it is to be seen in either older or younger embryos.

The largest mass (fig. 5) in proximity to the fore brain contains 35 germ-cells and extends through a dozen 4 micra sections.

In the former situation in this embryo-that is in the splanchnic mesoderm--there are 56 germ-cells in all. These are distributed as follows -48 in the tissues and 8 in the vessels. The cells in the blood vessels are in some cases larger than average caliber of the vessel so that its walls are pushed out noticeably on either side (fig. 4).

As regards the number of primordial germ-cells found in the embryos, in which they are present in the blood vessels, it may be said here that the figures given are only approximately correct. This applies to embryos with 25 somites, and especially to those which are younger, for in the latter, as will be seen, the germ-cells are found in the larger blood vessels, and the loss due to staining and dehydrating is greater than in the case of the older embryos, in which the primordial germ-cells are present in the smaller vessels only.

That the large cells within the blood vessels are primordial germ-cells, and that they pass out into the tissues, there can be no doubt. In the first place, they are identical in appearance with the germ-cells described in the splanchnic mesoderm of older embryos (compare figs. 2 and 4). This similarity is best observed in the embryo of 25 somites and the next younger one studied, which possesses 21 somites. In these two embryos, which have been called transition stages, because the primordial germ-cells are in the vessels as well as in the tissues, in neighboring sections germ-cells may be observed in both situations (figs. $7,8,9$ and 11). Thus, it will be noted that the germ-cells in both situations have the same size and shape (figs. 8 and 9). The mitochondria are similar, nor is there any nuclear difference. Cells within and without the vessels have the same amount of yolk material and the same conspicuous attraction-sphere (figs. 8 and 9$)$. 
Add to this similarity the facts (1) that, in embryos younger than 21 somites these large characteristics cells are all in the vessels; (2) that in embryos with 21 and 25 somites respectively they are in the tissues as well as in the vessels (figs. 4, 6, 7, 8 and 10); and (3) that, in embryos older than this they are found in the tissues of the splanchnic mesoderm alone; so that there can be no question as to the fact that the large, characteristic cells in the blood vessels are primordial germ-cells and are identical with the germ-cells found in the splanchnic mesoderm.

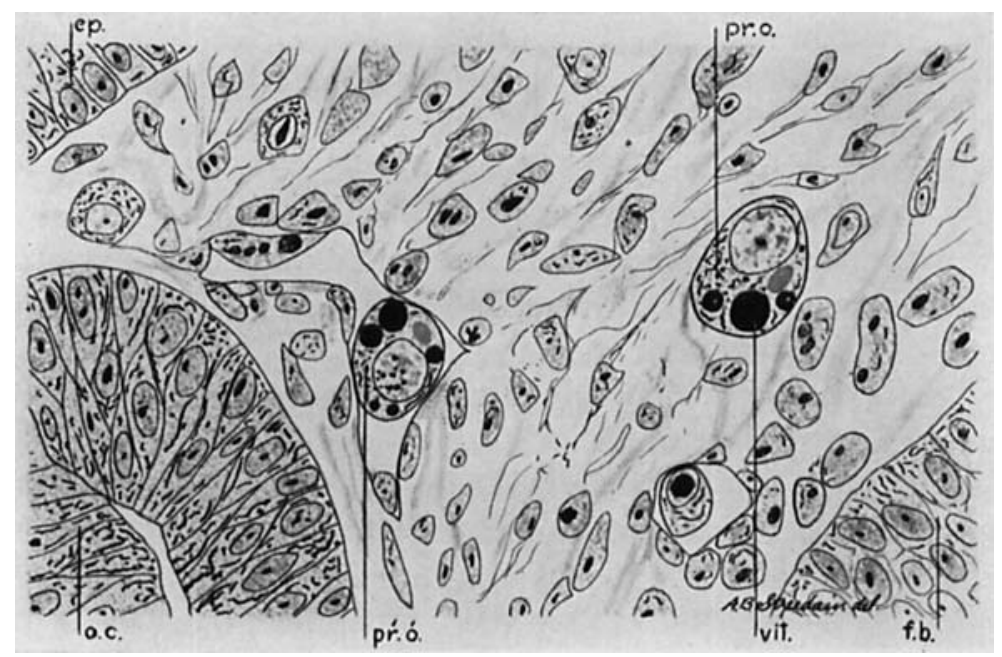

Fig. 6 Portion of a transverse section through the head region of a 21 somite embryo. Meves' fixation and Meves' iron-hematoxylin stain. $\times$ 787. pr.o., primordial germ-cell near fore-brain; $p r^{\prime} . o^{\prime}$., primordial germ-cell in a blood vessel near optic cup; vit., yolk sphere; f.b., fore-brain; o.c., optic cup; ep., epidermis.

In the embryo with 21 mesoblastic somites there are present altogether 73 primordial germ-cells. Of these, 13 are outside the blood-vessels, nearly all in the splanchnic mesoderm, and 60 are contained within vessels throughout the embryos and area vasculosa. Of these 60 , in the vessels of the splanchnic mesoderm, there are 30 , while in vessels of the head region 25 are to be seen (fig. 6). The distribution of the germ-cells in the splanchnic mesoderm is of interest in that all except two or three are caudad 
to the 18th somite. This applies to cells both in and without the vessels. In the splanchnic mesoderm region of this embryo two cells are present which are partly within and partly without the vessel (fig. 11).

In regard to the embryos with 25 and 21 somites several interesting facts should be recapitulated. In both, germ-cells are both within and without the blood vessels. In the younger embryo the cells in the vessels are more numerous, while in the older embryo this state of affairs is reversed. Also, let it be remembered that all investigators hitherto have failed to find the germcells in chick embryos with less than 22 somites.

In one series of an embryo with 19 mesoblastic somites there are present in all 82 primordial germ-cells. The distribution of these is markedly different from anything described hitherto. All, with the exception of 6 , are in the blood-vessels. They are found in the large (fig. 13) as well as small channels both of the area vasculosa and embryo proper. They are present in the heart and aortae as well as in the capillaries. They are never found in groups and in only one case could two be seen in a single field.

The germ-cells in this embryo as well as those still younger are characterized by an immense amount of yolk (figs. 12 and 13). This yolk material consists of spheres, having a diameter of 2-4 micra, and is massed principally in that portion of the cell in which is located the attraction-sphere. However, this yolk is not confined only to the pole of the cell occupied by the attraction-sphere, but usually surrounds the nucleus completely (fig. 12). This yolk is so abundant, that in preparations fixed with a fluid containing osmic acid, the other cell contents are seriously masked.

In embryos of this age the primordial germ-cells possess, in nearly all cases, amoeboid processes.

The stages of 16,12 and 10 somites respectively may be passed over rapidly since they present nothing essentially different from the 19 somite embryo as far as either the distribution or form of the germ-cells is concerned. Thus, the latter are found in the area vasculosa and in the developing vascular structures of the embryo proper. In the embryo possessing 12 somites, one germ- 
cell in particular is found in the heart. It must have moved in through the vessels by its own amoeboid properties, since the heart, in an embryo of this age, has not as yet begun to propel the blood. In fact this cell has a marked amoeboid appearance.

In embryos with 9 and 6 somites respectively the primordial germ-cells are all anterior and antero-lateral in respect to the embryo proper. Most of the germ-cells are present in the space between germ-wall entoderm and mesoderm. The few present in the mesodermal spaces have reached that position by migration from the former position. Some are present in the space between ectoderm and mesoderm; they have either passed through the mesoderm from the space between entoderm and mesoderm or have been left in that position by the outgrowth of mesoderm.

These germ-cells at this age have the large attraction-sphere so often referred to, as well as the abundant yolk. The nucleus is not so large as in older germ-cells and the chromatin does not exist in the two definite masses. Instead it is more evenly scattered throughout the nucleus and in some is reticular in appearance.

The germ-cells are very conspicuous, as, either isolated or in groups of two or three, they lie in the space between entoderm and mesoderm.

Fig. 7 Portion of a transverse section through a 21 somite chick embryo at the level of the 20th somite. Meves' fixation and Meves' iron-hematoxylin stain. $\times 1125$. pr.o., primordial germ-cell; vit., sphere of vitellus or yolk material; sp.m., splanchnic mesoderm; bl.v., lumen of blood vessel.

Fig. 8 ' Portion of a transverse section through a 21 somite chick at the level of of the 18th somite. Meves' fixation and Meves' iron-hematoxylin stain. $\quad \times 1125$. pr.o., primordial germ-cell; nuc., nucleus of primordial germ-cell; sp.m., splanchnic mesoderm; bl.v., lumen of blood vessel; end., nucleus of endothelial cell.

Fig. 9 Portion of a transverse section through a 21 somite chick embryo at the level of the 21st somite. Meves' fixation and Meves' iron-hematoxylin stain. $\quad \times$ 1125. pr.o., primordial germ-cell; sp.m., splanchnic mesoderm; bl.v., lumen of blood vessel; ent., entoderm.

Fig. 10 Portion of a transverse section through a 21 somite chick embryo at the level of the 19th somite. Meves' fixation and Meves' iron-hematoxylin stain. $\quad \times$ 1125. pr.o., primordial germ-cell; pr.'o.', primordial germ-cell dividing; sp.m., splanchnic mesoderm; bl.v., lumen of blood vessel; end., nucleus of endothelial cell; ent., entoderm. 

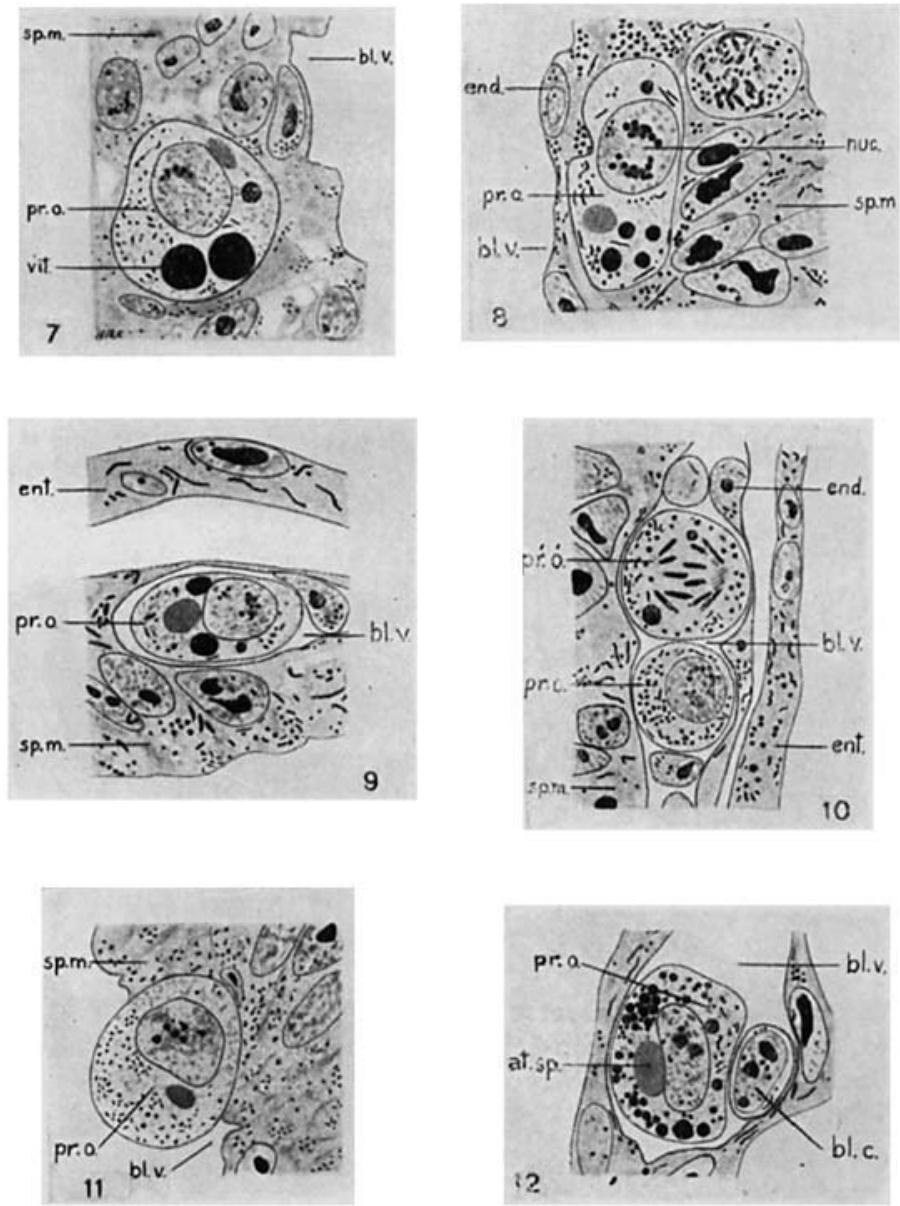

Fig. 11 Portion of transverse section through a 21 somite chick embryo. Meves' fixation and Meves' iron-hematoxylin stain. $\times 1125 . \quad$ pr.o., p rimordial germ-cell; sp.m., splanchnic mesoderm; bl.v., lumen of blood vessel.

Fig. 12 Portion of a transverse section through a 19 somite chick embryo. Meves' fixation and Meves' iron-hematoxylin stain. $\times 1125$. pr.o., primordial germ-cell; bl.c., blood cell; bl.v., lumen of blood vessel. 


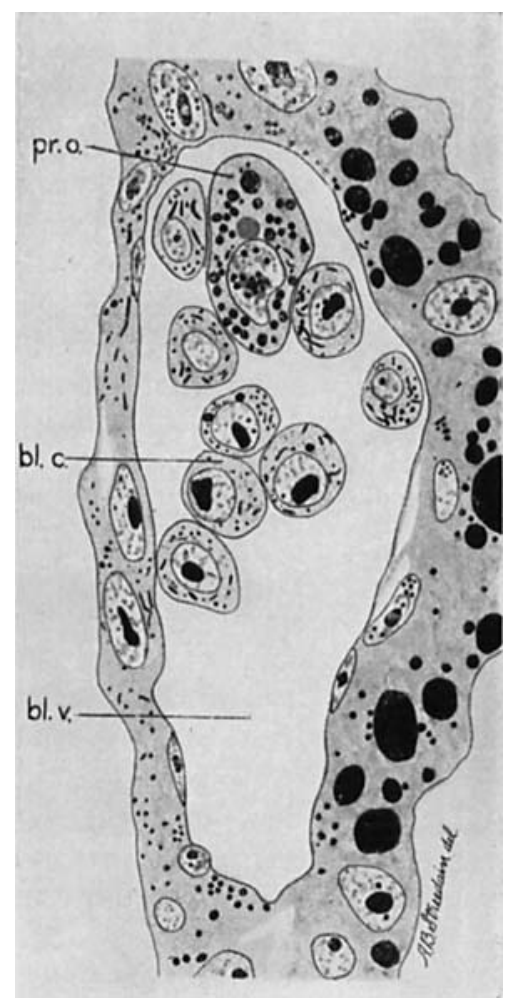

Fig. 13 Portion of a transverse section through a 19 somite chick embryo. Meves' fixation and Meves' iron-hematoxylin stain. $\times 1125$. pr.o., primordial germ-cell; at.sp., attraction-sphere of germ-cell; bl.c., blood cell; bl.v., lumen of blood vessel.

\section{Origin of the germ-cells}

Dantschakoff ('08) has described certain cells in the chick embryo, which arise anterior and lateral to the primitive streak and young embryo. They originate, she states, from the margin of the germ-wall entoderm. They begin to appear during the primitive streak stage and continue to be produced until the embryo has 3 pairs of somites. They are large, have a large round nucleus and an abundance of yolk, and are especially characterized by their amoeboid properties. Because of their amoeboid 
tendencies she called them entodermal wander-cells. They appear at first in groups, between the germ wall entoderm and ectoderm, anterior to the forming embryo, before mesodermal tissue has grown out into that region. They then enter the mesoderm and forming blood-vessels, and, either by their own amoeboid powers, or aided by the vascular circulation penetrate into every part of the area vasculosa and embryo. Although for some time in the vascular system yet they are not blood cells as is evidenced by their appearance, origin and fate. Some of these entodermal wander-cells enter the embryonic tissues, leaving the blood-vessels by their power of diapedesis, and degenerate. Others undergo a like fate in the blood-vessels themselves. The remainder disappear from the blood-vessels and by the time the embryo has 22 somites all have gone. Although the fate of those which do not degenerate is unknown, yet Mlle. Dantschakoff believes that they have no share in tissue formation.

These entodermal wander-cells of Dantschakoff are in reality the primordial germ-cells of the chick. There is a close agreement as far as origin is concerned, for I also find that the germ-cells originate from certain cells of the germ-wall entoderm near its junction with the area pellucida. I find also that they are produced during the primitive streak stage and in the embryo possessing at least 3 somites.

These germ-cells arise in a region of the germ-wall anterior to the forming embryo and also antero-lateral. This region, just at the junction of area pellucida and germ-wall, has roughly the shape of a crescent, the concavity being turned towards the embryo; the horns extend caudalward on either side (fig. 15). In this crescent shaped region many of the germ-wall entodermal cells resemble the germ-cells (fig. 14). They have the round nucleus, great quantity of yolk and the large conspicuous attraction-sphere.

That these particular germ-wall entodermal cells are producing the primordial germ-cells, is proven by the fact that in the primitive streak stage, before the appearance of mesoderm anterior to the embryo, the germ-cells are grouped in the space between entoderm and ectoderm in this immediate neighborhood; the 
germ-cells cytologically are very similar to the cells of the germwall near its border (fig. 14); mitoses are also seen in these cells (fig. 14).

When the mesoderm reaches this region anterior to the embryo, which it does relatively late, the germ-cells enter the mesoderm and the forming blood-vessels.

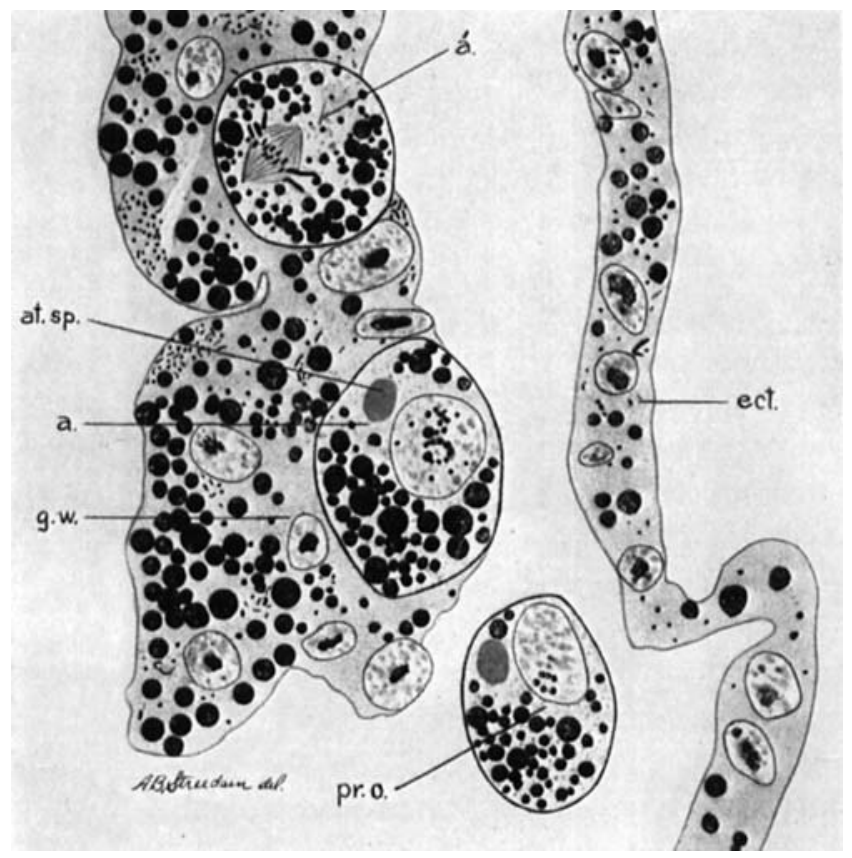

Fig. 14 Portion of a transverse section through an embryo of primitive streak stage development. Meves' fixation and Meves' iron-hematoxylin stain. $\times 1125$. pr.o., primordial germ-cell; $a_{\text {., }}$ cell of germ-wall, which resembles primordial germ-cell; $a^{\prime}$. , cell of germ-wall dividing; at.sp., attraction-sphere of germ-wall cell; g.w., germ-wall entoderm; ect., ectoderm.

As regards the history of the entodermal wander-cells in the blood there is also a close agreement with that of the germ-cells. However, a majority of the germ-cells do not degenerate in the blood stream or in the tissues. Only a few of the germ-cells leave the vessels before a stage of 21 somites is reached and only a few degenerate. 
'The statement made by Dantschakoff, that the entodermal wander-cells leave the blood entirely by the time the embryo has 22 somites, is of interest in view of the fact that at that stage the

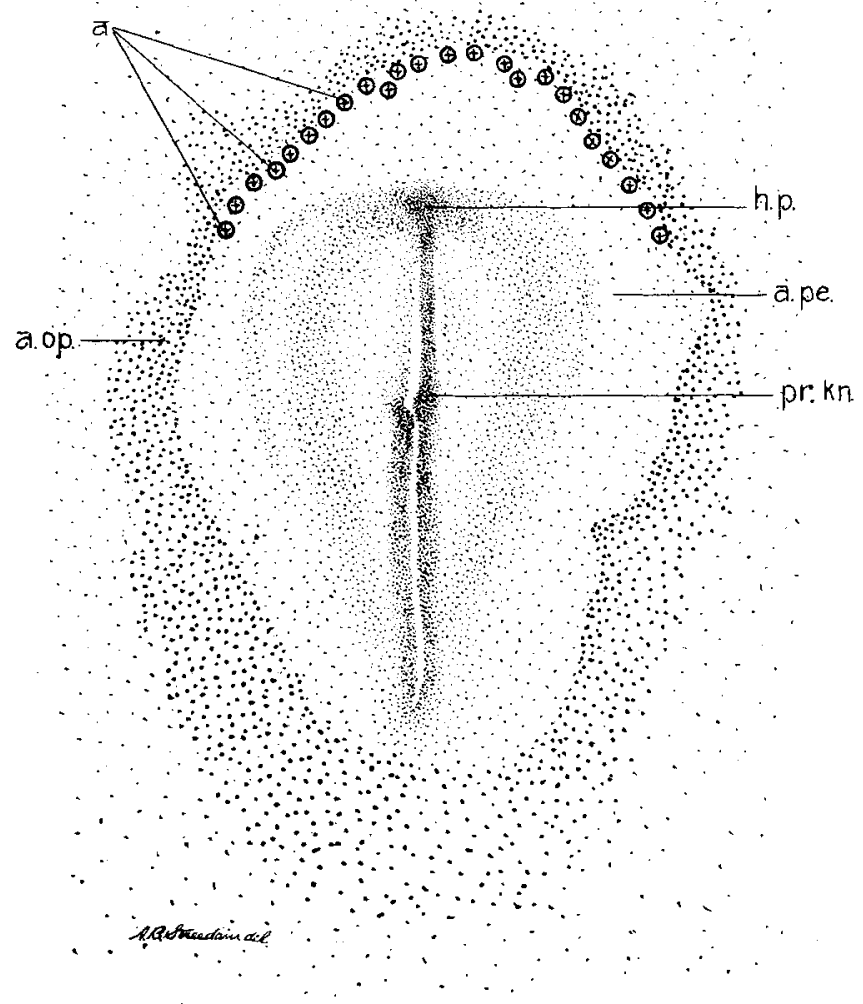

Fig. 15 Surface view of a primitive streak stage of a chick embryo, viewed by transmitted light (semi-diagrammatic). Zeiss ocular 2, Zeiss objective $A_{3}$. This figure is intended to show the point at which the primordial germ-cells arise. The circles $a$, at the junction of germ wall and arca pellucida, indicate this region. $a$. , region in which the primordial germ-cells arise; h.p., head process; pr.kn., primitive knot; a.op., area opaca; a.pe., area pellucida.

germ-cells are leaving the vessels of the splanchnic mesoderm and passing into the tissues of the splanchnic mesoderm near the coelomic angle. 


\section{SLMMARY AND CONCLUSIONS}

1. The primordial germ-cells arise anterior and antero-lateral to the embryo in a specialized region of germ-wall entoderm just at the margin of the area pellucida. This region has roughly the shape of a crescent and the germ-cells arise during the primitive streak stage and until the embryo has about 3 somites. The concavity of this crescent is towards the embryo and the horns extend caudalward on either side.

2. Owing to the late appearance of mesoderm in this region, the primordial germ-cells at first are in the space between entoderm and ectoderm. Later, thanks to their amoeboid power, they enter the mesoderm and the forming blood vessels of the mesoderm.

3. They are at first carried by their own movement, and later by that of the blood to all parts of the embryo and vascular area. They remain generally distributed in this way until the embryo has about, 20 somites.

4. In embryos with about 20 to 22 pairs of somites, the primordial germ-cells, while generally distributed throughout the embryo in the blood-vessels, are becoming relatively more numerous in the vessels of the splanchnic mesoderm. This increase in the number of the germ-cells in the vessels of the splanchic mesoderm may be in part only apparent, that is, a degeneration of some may have occurred elsewhere, or, it may be a real increase due to some influence, probably of a chemotactic nature, exerted in the region of the future gonad. At this period the great majority of the cells are found in the vessels, but a few, chiefly in the splanchnic mesoderm, are present in the tissues. In some cases they are present in the wall of the vessel, as if fixed in the act of leaving the vessel for the tissues (fig. 11).

5 . In embryos with about 23 to 25 pairs of somites the majority of the primordial germ-cells are found in the mesodermal tissue of the splanchnic mesoderm near the angle of the coelom. A few cells are still present in the blood-vessels; at the 25 th somite stage, in one embryo, in addition to the few found in the vessels of the splanchnic mesoderm, four masses of germ-cells are in the 
vessels of the head. This is an abnormal condition, since the germ-cells in all the other embryos studied, are never grouped in this way. The embryo with 25 somites is the oldest in which germ-cells are found in the vessels.

The embryo with about 22 to 23 segments is the youngest in which the primordial germ-cells bave hitherto been described in the bird. Nussbaum ('80) and Keibel and Abraham ('00) in the chick, and Hoffmann ('93) in Gallinula, Sterna and Haematopus described the germ-cells at 23 somites in the splanchnopleure.

6. In embryos possessing about 26 to 29 somites the primordial germ-cells are found in the splanchnic mesoderm near the radix mesenterii.

7. In embryos with 30 to 33 somites the primordial germ-cells are in the radix mesenterii and coelomic epithelium on both sides of the coelomic angle. They remain in this position until the formation of the gonad begins when they gradually pass into that organ.

\section{BIBLIOGRAPHY}

ArJuen, B. M. 1903 The origin of the sex-cells of Chrysomis. Anat. Anz., Bd. 29.

1909 The origin of the sex-cells of Amia and Lepidosteus. Anat. Rec., vol. 3.

BEAnd, J. 1904 The germ-cells. Part 1. Journ. Anat. and Phys, vol. 38.

Bensley, R. R. 1911 The pancreas of the guinea-pig. Amer. Jour. Anat., vol. 12 , pp. $297-388$.

von Berenberg-Gossler 1912 Die Urgeschlechtszellen des Hühnerembryos aus 3 and 4 Bebrütungstage. Arch. Mik. Anat., Bd. 81 .

Balriant, E. G. 1885 Contribution a l'etude de la formation des organes sexuels chez les insectes. Recueil Zoologique, Suisse.

Dantschakoff, W. 1908 Entwicklung des Blutes bei den Vögeln. Anat. Hefte, Bd. 37 , S. 471.

d'Hollander, F. 1904 Recherches sur l'oogenese et le noyau vitellin de Balbiani chez les oiseaux. Arch. d'Anatomie Mic., T. 7.

Dopds, G. S. 1910 Segregation of the germ-cells of the teleost Lophius. Jour. Morph. vol. 21, p. 563.

Eigenmann, C. H. 1892 On the precocious segregation of the sex-cells in Cymatogaster. Journ. Morph., no. 5, p. 481.

1897 Sex differentiation in the viviparous teleost Cymatogaster. Arch. Arch. f. Entw'mech., Bd. 4, p. 125. 
FELIX, W. 1906 Die Entwicklung der Keimdrüsen and ihrer Ausführungsgange. Hand. d. Entw. von O. Hertwig.

Fuss, A. Über dic Geschlechtszellen des Menschen und der Säugetiere. Arch. für Mikros. Anat., Bd. 81, Heft. 1.

1911 Über Extraregionare Geschlechtszellen bei einen Menschlichen Embryo von vier Wochen. Anat. Anz., Bd. 39.

HaEcker, V. 1897 Dic Keimbahn von Cyclops. Arch. f. Mik. Anat., Bd. 49.

Hegner, R. W. 1909 The origin and early history of the germ-cells in some chrysomelid beetles. Jour. Morph., no. 20.

Hoffmann, C.K. 1893 Etude sur le developpement de l'appareil urogenital des oiseaux. Verhand. der Koninklyte Akademie von Wetenschoppen, Amsterdam, Tweedie Sectie, vol. 1.

JARvis, Miss 1908 The segregation of the germ-cells of Phrynosoma cornutum: Preliminary note. Biol. Bulletin, vol. 15, p. 119.

Nussbaum, M. 1901 Zur Entwicklung der Gesehlechts beim Huhn. Anat. Anz.

Rubaschio , W. 1907a Uber das erste Auftreten und Migration der Keimzellen bei Vögelembryonen. Anat. Hefte., Bd. 39.

1907 Zur Frage von der Entstehung der Keimzellen bei Säugetierembryonen. Anat. Anz., Bd. 31.

1910 Chondriosomen und Differenzierungsprozesse bei Säugetierembryonen. Anat. Hefte, Bd. 41.

Sexon, R. 1887 Die indifferente Anlage der Keimdrüsen beim Hühnchen und ihre Differenzierung zum Hoden. Jena Zeitsehr. Naturwiss., Bd. 21.

Tschaschin, S. 1910 Utber die Chondriosomen der Urgeschlechtszellen bei Vögelembryonen. Anat. Anz., vol. 37.

Waldeyer, W. 1870 Eierstock und Ei. Leipzig, Englemann.

Woons, F.A. 1902 Origin and migration of the germ-cells in Acanthias. Amer. Jour. Anat., vol. 1, p. 307. 